\title{
THE AUTHORITY OF VILLAGE CREDIT UNION AS THE SUBJECT OF LIAB ILITY RIGHTS
}

\section{Jeanne Wiryandani Ratmaningrum,SH., Prof. Dr. IGN Wairocana,SH.,MH., Dr. Putu Gede Arya Sumerthayasa,SH.,MH}

\section{ABSTRACT}

According to the Bali Provincial Regulation No. 8 concerning Village Credit Union (hereinafter referred to as LPD) Article 2 paragraph (1) states that: LPD is a village-owned financial union conducting business in the village and for the benefit of the villagers. This is confirmed by the presence of the Decision of the Third Big Meeting by Village Assembly (MDP) Bali No. 009 / SK-PA III / MDP Bali /Vffl /2014 Article I paragraph (1), namely, the Village Credit Union is one of the possessions of the village.

This type of research used in this thesis is a normative study. Normative study is the one that examines the level of legal norms, finding the non-existence of the LPD status as a legal subject of liability rights, so there is a legal vacuum in which the status of the LPD as the subject of a liability rights is not stipulated in the legislation and these problems will be a legal discovery.

LPD is the possession of the village, so LPD cannot be the legal subject of liability right because the village itself has not been the subject of law. So the security liability agreement made by LPD is invalid because it does not qualify his legitimate agreements written in Article 1320 paragraph (4) of Civil Code regarding lawful cause or legal cause.

Keyword : LPD, Legal Subject, Liability Rights

\section{B A B I PENDAHULUAN}

\subsection{Latar Belakang Masalah}

Pada Tahun 1984 pemerintah Bali melalui Surat Keputusan (SK) Gubernur Nomor : 972 mencetuskan pendirian Lembaga Perkreditan Desa (selanjutnya disingkat dengan LPD), lembaga keuangan yang menghimpun dana dari masyarakat desa dan kemudian menyalurkannya dalam bentuk kredit. LPD merupakan duwe desa pakraman yang memiliki karakter khas sebagai lembaga komunitas adat.

LPD menggunakan Pasal 18A dan pasal 18B UUD RI 1945 sebagai dasar konstitusinya, yang memuat ketentuan dalam pasal $18 \mathrm{~A}$ bahwa pemerintah daerah propinsi, kabupaten dan kota, haruslah memperhatikan kekhususan dan keragaman suatu daerah, yang kemudian dipertegas oleh pasal 18B bahwa Negara mengakui dan menghormati satuan- satuan pemerintahan daerah yang bersifat khusus atau istimewa, serta mengakui dan menghormati satuansatuan masyarakat hukum adat serta hak-hak tradisionalnya sepanjang masih hidup dan sesuai dengan perkembangan masyarakat dan prinsip Negara Kesatuan Indonesia. ${ }^{1}$

Ketentuan konstitusi ini oleh Pemerintah Provinsi Bali ditindaklanjuti dengan pembentukan Peraturan Daerah Nomor 8 Tahun 2002 tentang Lembaga Perkreditan Desa sebagaimana telah diubah beberapa kali dan terakhir diubah dengan Peraturan Daerah Provinsi Bali Nomor 4 Tahun 2012 tentang Perubahan Kedua Atas Peraturan Pemerintah Daerah Propinsi Bali Nomor 8 Tahun 2002 tentang Lembaga Perkreditan Desa.

LPD adalah lembaga keuangan yang bersifat sui generis. Sui generis berarti

${ }^{1}$ Pasal 18A dan Pasal 1 8B Undang-Undang Dasar Negara Republik Indonesia Tahun 1945. 
khusus, sesuatu yang bersifat sangat khas, hanya ada satu pada jenisnya atau bersifat sangat berbeda dari yang lainnya dalam lingkungan jenis itu. ${ }^{2}$ LPD sebagai suatu lembaga yang didirikan khusus untuk kepentingan demi mensejahterakan masyarakat desa pakraman, dalam kegiatannya hanya melayani masyarakat desa pakraman saja, LPD tidak melayani masyarakat diluar dari wilayah desa pakraman tempat dimana LPD tersebut beroperasi. Oleh karena itu LPD dikatakan sebagai lembaga keuangan yang memiliki sifat khusus.

$$
\text { Sebagai lembaga keuangan }
$$

komunitas LPD dibentuk oleh suatu satuan komunitas, yang beroperasi dalam suatu wilayah komunitas, melayani transaksi keuangan dilingkungan komunitas dan juga memenuhi tujuan-tujuan komunitas. LPD sebagai wadah ekonomi desa didalam memberikan pelayanan pemberian kredit dipertegas dalam Pasal 7 ayat (1) sub b Peraturan Daerah Nomor 8 Tahun 2002 yang menyebutkan "memberikan pinjaman hanya kepada krama desa". Agar pemberian pinjaman dapat berjalan mulus, maka diperlukan adanya jaminan yang diserahkan oleh peminjam kepada yang dipinjami. Jaminan biasanya berupa benda tetap yaitu sertifikat tanah.

Bagaimana bila yang meminjam uang adalah LPD itu sendiri dengan mengunakan jaminan benda tetap yaitu sertifikat tanah. Apakah LPD dapat menjadi subyek hukum hak tanggungan sebagai debitur? Hak Tanggungan

${ }^{2}$ Henry Campbell Black, Black's Law Dictionary, Fifth Edition, St. Paul Minn.West Publishing Co., USA, 1977, hlm.1286. berdasarkan Pasal 1 ayat (1) Undangundang Nomor 4 Tahun 1996 tentang Hak Tanggungan (selanjutnya disingkat dengan UUHT) adalah: "Hak Tanggungan atas tanah beserta bendabenda yang berkaitan dengan tanah, yang selanjutnya disebut Hak Tanggungan, adalah hak jaminan yang dibebankan pada hak atas tanah sebagaimana dimaksud dalam Undangundang Nomor 5 Tahun 1960 tentang Peraturan Dasar Pokok-pokok Agraria, berikut benda-benda lain yang merupakan satu kesatuan dengan tanah itu, untuk pelunasan utang tertentu, yang memberikan kedudukan yang diutamakan kepada kreditor tertentu terhadap kreditor-kreditor lain."

\subsection{Rumusan Masalah}

Dari latar belakang diatas maka dapat dirumuskan beberapa masalah antara lain :

1.2.1 Apakah Lembaga Perkreditan Desa berwenang sebagai subjek hukum hak tanggungan?

1.2.2 Bagaimana akibat hukum dari perjanjian yang dibuat oleh Lembaga Perkreditan Desa sebagai debitur dalam suatu perjanjian hak tanggungan?

\subsection{Tujuan Penelitian}

\subsubsection{Tujuan Umum}

Penelitian ini secara umum bertujuan untuk mengetahui syaratsyarat subjek hukum Hak Tanggungan dan untuk mengetahui kesatuan perjanjian hak tanggungan.

\subsubsection{Tujuan Khusus}

Tujuan khusus yang hendak dicapai dari penelitian ini adalah :

a. Untuk mengetahui kedudukan Lembaga Perkreditan Desa sebagai subjek hukum dalam Hak Tanggungan. 
b. Untuk mengetahui Perjanjian yang dibuat oleh Lembaga Perkreditan Desa sebagai debitur dalam perjanjian Hak Tanggungan.

\subsection{Manfaat Penelitian}

\subsubsection{Manfaat Teorits}

Manfaat secara teortitis bagi pengembangan ilmu pengetahuan hukum, khususnya dalam bidang hukum hak tanggungan.

\subsubsection{Manfaat Praktis}

Secara praktis hasil penelitian ini bagi kalangan akademis dan bagi masyarakat umum hasil penelitian ini dapat digunakan sebagai informasi untuk mengetahui status subjek hukum LPD dalam perjanjian hak tanggungan.

\subsection{Landasan Teoritis}

Landasan teoritis dalam penelitian ini menggunakan tiga teori yaitu Teori Kewenangan, Teori Badan Hukum dan Teori Perjanjian untuk memperjelas dalam memberikan suatu gambaran mengenai permasalahan diatas, yaitu :

\section{Teori Kewenangan}

Wewenang menurut H.D Stout mengatakan : "bevoegdheid is een begrip int het bestuurlijke organisasitierecht, wat van worder omschreven als het geheel van regels dat betrekking heft op de verkrijiging en uitoefening van bestuurrechselijke rechtsverkeer". 3 Maksudnya wewenang merupakan pengertian yang dapat dijelaskan sebagai keseluruhan aturan-aturan yang berkenaan dengan perolehan dan penggunaan wewenang pemerintahan oleh subyek hukum public di dalam hubungan hukum public.

Teori Kewenangan digunakan untuk menelaah bahwa wewenang LPD sebagai

${ }^{3}$ H.D Stout, 1994, de Betekenissen van de wet, W.E.J. Tjeen Willink, zwole, hlm.102 (maarseven van hench, bevoegdheid dalam PNC, akkermaans, dkk,1985, agleme begrippen Van staats Recht, Deed I,W.E.J. Tjeen willink Zwolle). subyek hukum hak tanggungan harus dapat ditunjukan dasar hukumnya. Penggunaan wewenang juga dimaksudkan untuk mengendalikan perilaku subjek hukum.

2. Teori Badan Hukum

Subyek hukum adalah pendukung hak dan kewajiban, pendukung hak dan kewajiban ialah individu (orang) dan badan hukum (perusahaan, organisasi dan instansi).

Menurut Abdulkadir Muhammad, subjek hukum adalah pendukung hak dan kewajiban. Pendukung hak dan kewajiban itu disebut orang. Orang dalam arti hukum terdiri dari manusia pribadi dan badan hukum. Manusia pribadi adalah subjek hukum dalam arti biologis, sebagai gejala alam, sebagai mahluk budaya yang berakal, berperasaan dan berkehendak. Badan hukum adalah subjek hukum dalam artiam yuridis sebagai gejala dalam hidup bermasyarakat, sebagai badan ciptaan manusia berdasarkan huum, mempunyai hak dan kewajiban seperti manusia pribadi. ${ }^{4}$

Menurut Teori Fiksi bahwa kepribadian hukum atas kesatuan-kesatuan lain daripada manusia adalah hasil khayalan, dalam tesis ini LPD dianggap badan hukum oleh masyarakat yang dapat melakukan perbuatan selayaknya subyek hukum. Menurut Teori Organik bahwa badan hukum adalah suatu badan yang membentuk kehendaknya dengan perantaan alat-alat atau organ-organ badan tersebut. LPD mempunyai organinasi yang terdiri dari pengurus dan pengawas jelas disebutkan dalam Pasal 10 Perda Nomor 8 Tahun 2002 Teori Perjanjian.

3. Teori Perjanjian

Menurut teori baru yang dikemukankan oleh Van Dunne, sebagaimana dikutip oleh Salim H.S yang diartikan dengan perjanjian

${ }^{4}$ Abdulkadir Muhammad, 2000, Hukum Perdata Indonesia, Citra Aditya Bandung, hlm. 27. 
adalah : Suatu hubungan hukum antara dua pihak atau lebih berdasarkan kata sepakat untuk menimbulkan akibat hukum. Teori baru tersebut tidak hanya melihat perjanjian semata-mata, tetapi juga harus dilihat perbuatan sebelumnya atau yang mendahuluinya. Ada tiga tahap dalam membuat perjanjian menurut teori hukum baru, yaitu :

1) Tahap pracontraktual, yaitu adanya penawaran dan penerimaan,

2) Tahap contractual, yaitu adanya persesuaian pernyataan kehendak antara para pihak,

3) Dan tahap post contractual, yaitu pelaksaan perjanjian. ${ }^{5}$

Dalam Penulisan Tesis ini, penulis akan menggunakan Teori Perjanjian didalam membahas permasalahan kedua mengenai akibat hukum dari perjanjian yang dibuat oleh LPD sebagai debitur dalam perjanjian hak tanggungan apakah sudah memenuhi syarat sahnya perjanjian.

\subsection{Metode Penelitian}

\subsubsection{Jenis Penelitian}

Jenis penelitian yang diterapkan adalah penelitian hukum normative, penelitian ini dilakukan karena menemukan adanya kekosongan norma yaitu dalam Undang-Undang Nomor 4 Tahun 1996 tentang Hak Tanggungan pasal 9 mengenai pemegang hak tanggungan adalah orang perseorangan atau badan hukum yang berkedudukan sebagai pihak berpiutang, tidak dijelaskan lebih lanjut mengenai badan hukum yang dimaksud. Sedangkan LPD sendiri bukan badan hukum.

\subsubsection{Jenis Pendekatan}

Dalam penelitian tesis ini, jenis pendekatan yang digunakan adalah pendekatan perundang-undangan (The

${ }^{5}$ Salim H.S., 2010, Hukum Kontrak Teori dan Teknik Penyusunan Kontrak, cet.7, Sinar Grafika, Jakarta, hlm. 26.
Statute Approach) dan pendekatan konseptual (Conceptual Approach).

\subsubsection{Sumber Data}

a. Data Primer yaitu data yang diperoleh dari perundang-undangan, peraturan daerah, paruman agung dan SK gubernur.

b. Data Sekunder yaitu bahan pustaka yang berisikan informasi pendukung bahan primer seperti buku-buku, majalah, jurnal hukum dan karya ilmiah.

\subsubsection{Teknik Pengumpulan Data}

Peneliti menggunakan studi kepustakaan karena peneliti banyak melakukan penelitian dengan banyak membaca, mencari peraturan perundangundangan yang berkaitan dengan penulisan tesis ini, dan melakukan penelurusan buku-buku hukum

\subsubsection{Teknik Analisis Data}

Tenik analisis yang dipergunakan dalam penelitian ini dilakukan dengan menganalisis bahan-bahan hukum yang telah terkumpul, teknik analisis bahan hukum yang digunakan yaitu deskripsi, sistematisasi, evaluasi, interpretasi dan argumentasi.

\section{B AB II \\ PEMBAHASAN}

\subsection{Kedudukan Lembaga Perkreditan Desa Sebagai Debitur}

Dalam ilmu hukum dikenal 2 subyek hukum, yaitu orang pribadi (natural person atau naturlijk person) dan badan hukum (legal entity atau recht person). Badan hukum berasal dari bahasa Latin yang disebut Corpus atau dalam bahasa Inggris dikenal dengan Body. Proses lahirnya sebuah badan hukum terjadi melalui suatu proses hukum, berbeda dengan orang pribadi yang prosesnya sebagai subyek 
hukum lahir secara alamiah. Dengan kata lain, perseroan dapat disebut sebagai mahluk badan hukum yang berwujud artifisial (kumstmatig, artificial) yang dicipta oleh negara melalui sebuah proses hukum. ${ }^{6}$

Manusia sebagai subyek hukum diatur dalam ketentuan perundangundangan yaitu dalam Pasal 27 UUD RI 1945, Kitab Undang-Undang Hukum Perdata Buku I tentang orang dan dalam UU No.5 Tahun 1960. Disamping manusia ada pendukung hak-hak dan kewajiban-kewajiban yang kita namakan badan hukum (rechts person) untuk membedakan dengan manusia (naturlijk person). Jadi ada suatu bentuk hukum, yaitu badan hukum yang dapat mempunyai hak-hak, kewajibankewajiban hukum dan dapat mengadakan hubungan hukum.

Kemampuan untuk mendukung hak dan kewajiban disebut kewenangan hukum (rechtsbehovegd). Kewenangan hukum diberikan kepada subjek hukum oleh hukum objektif. Menurut L.J. Van Apeldoorn kewenangan hukum diberikan kepada tiap-tiap orang. Dengan demikian orang adalah subjek hukum. ${ }^{7}$

Badan hukum sebagai subyek hukum diatur dalam peraturan perundang-undangan. Yaitu dalam KUHPerdata, Kitab Undang-Undang Hukum Dagang (KUH Dagang), UU No. 40 Tahun 2007 tentang Perseroan Terbatas, UU No. 25 Tahun 1992 tentang Perkoperasian, dan UU No. 16 Tahun 2001 tentang Yayasan. Suatu

${ }^{6}$ M. Yahya Harahap, 2009, Hukum Perseroan Terbatas, Jakarta: Sinar Grafika, hlm. 36.

${ }^{7}$ Adul Rachmad Budiono, 2005, Pengantar Ilmu Hukum, Bayumeda, Malang, hlm. 52. badan hukum dapat dikatakan dan diakui sebagai badan hukum jika memenuhi ketentuan yaitu badan hukum tersebut mendapat pengakuan dan pengesahan secara hukum, diyakini sebagai subyek hukum oleh masyarakat, memiliki harta kekayaan, memiliki tujuan-tujuan tertentu dan memiliki kehendak dengan perantaraan alat-alat atau organ-organ badan tersebut.

Dalam UU No. 40 Tahun 2007 tentang Perseroan Terbatas merupakan peraturan khusus yang mengatur mengenai badan hukum Perseroan Terbatas (PT). Selanjutnya dalam penulisan tesis ini disingkat menjadi UUPT 2007. Dalam Pasal 1 UU PT disebutkan bahwa Perseroan Terbatas yang selanjutnya disebut Perseroan, adalah badan hukum yang merupakan persekutuan modal, didirikan berdasarkan perjanjian, melakukan kegiatan usaha dengan modal dasar yang seluruhnya terbagi dalam saham dan memenuhi persyaratan yang ditetapkan dalam undang-undang ini serta peraturan pelaksanaannya.

Subyek hak tanggungan diatur dalam Pasal 8 ayat (1) dan Pasal 9 UUHT, yang memuat tentang ketentuan subyek hukum dalam hak tanggungan yaitu :

a. Pemberi Hak Tanggungan adalah orang perorangan atau badan hukum yang mempunyai kewenangan untuk melakukan perbuatan hukum terhadap obyek Hak Tanggungan pada saat pendaftaran Hak Tanggungan itu dilakukan.

b. Pemegang Hak tanggungan adalah orang perseorangan atau badan hukum 
yang berkedudukan sebagai pihak yang berpiutang.

LPD tidak bisa menjadi subjek hukum hak tanggungan walaupun dapat dikatakan LPD telah memenuhi unsurunsur sebagai subyek hukum yaitu mempunyai modal atau harta kekayaan sendiri yang berasal dari warga desa pakraman dimana LPD tersebut berada, LPD juga memiliki alat/organ yaitu pengurus, pengawas dan angota LPD, dapat digugat dan menggugat, serta mempunyai tujuan yaitu mensejahterakan krama desa pakraman. Keberadaan LPD juga telah diakui keberadaannya oleh UU LKM, LPD dinyatakan diakui keberadaanya berdasarkan hukum adat dan tidak tunduk terhadap UU LKM ini, hal ini sesuai dengan pernyataan Bab XIII Pasal 39 angka (3).

LPD bukanlah badan hukum, akta pendiriannya tidak ada dan untuk mendirikan LPD tidak seperti mendirikan bank atau koperasi yang diperlukan modal tetapi LPD berdiri karena prakarsa dari masyarakat desa karena LPD adalah milik masyarakat desa, untuk keperluan masyarakat desa dan diurus sendiri oleh masyarakat desa. Jadi LPD tidak bisa menjadi subyek hukum hak tanggungan karena LPD bukan badan hukum, yang dapat menjadi subyek hak tanggungan adalah pribadi dari pengurus atau ketua LPD tersebut termasuk juga dengan objek hak tanggungan yang dibebankan adalah obyek daripada milik pribadi bukan milik LPD sehingga bila terjadi keadaan tidak mampu memenuhi kewajiban dari hutang tersebut adalah menjadi resiko dari pengurus atau ketua LPD yang dengan sukarela mengikatkan dirinya pada perjanjian hak tanggungan tersebut.

Teori Fiksi mengumpamakan seolah-olah badan hukum sebagai manusia yang sesungguhnya badan hukum itu tidak ada, sedangkan sebaliknya teori organ memandang badan hukum itu suatu realitas yang sebenarnya sama dengan manusia. ${ }^{8}$

Menurut teori organ dari Von Gierki yang menyatakan bahwa badan hukum bukan merupakan sesuatu hal yang fiktif melainkan sebagai realitas yang tidak berbeda dengan manusia dalam pergaulan hukum. Dalam teori ini, badan hukum bukanlah suatu pribadi yang sesungguhnya melainkan badan hukum mempunyai kehendak atau kemauam sendiri yang dibentuk melalui alat pelengkapnya yaitu seperti pengurus, pengawas dan anggotaanggotanya. Jika dikaitkan dengan LPD maka LPD memenuhi unsur-unsur mempunyai alat atau organ yang dapat dilihat dari adanya pengurus dan pengawas yang diangkat dan diberhentikan oleh warga desa melalui rapat desa, LPD juga mempunyai anggota yang berasal dari seluruh warga atau krama desa pakraman dimana LPD tersebut berada.

\subsection{Akibat Hukum Dari Perjanjian Hak Tanggungan Oleh Lembaga Perkreditan Desa Sebagai Debitur}

Syarat sah perjanjian diatur dalam Pasal 1320 KUHPerdata, ada 4 (empat) syarat fundamental yang harus dipenuhi dalam perjanjian agar dapat dikatakan

${ }^{8}$ Suparmo, Gatot, 2009, Hukum Perseroan Terbatas, Jakarta : Djambatan, hal. 7. 
sah, yaitu : suatu perjanjian diatur dalam KUHPerdata yaitu dalam Pasal 1320 KUHPerdata. Ada empat syarat fundamental yang harus dipenuhi agar perjanjian/kontrak dapat dinyatakan sah, yaitu:

1. Sepakat mereka yang mengikatkan diri.

2. Kecakapan untuk membuat perjanjian.

3. Suatu hal tertentu.

4. Suatu sebab yang halal.

Subyek Hak tanggungan adalah pemberi hak tanggungan dan pemegang hak tanggungan. Pemberi hak tanggungan adalah orang atau badan hukum yang mempunyai kewenangan untuk melakukan perbuatan hukum terhadap obyek hak tanggungan.

Notaris dalam profesinya sesungguhnya merupakan instansi yang dengan akta-aktanya menimbulkan alatalat pembuktian tertulis dengan mempunyai sifat otentik. Keotentikan suatu akta sangat ditentukan oleh terpenuhinya unsur-unsur yang ada dalam Pasal 1868 Kitab Undang-Undang Hukum Perdata. Pasal 1868 Kitab Undang-Undang Hukum Perdata menyebutkan : "suatu akta otentik ialah suatu akta yang di dalam bentuk yang ditentukan oleh Undang-Undang, di buat oleh atau dihadapan pegawai-pegawai umum yang berkuasa untuk itu di tempat dimana akta itu di buatnya." 9

Berkaitan dengan perjanjian hak tanggungan yang dilakukan oleh LPD berhubungan dengan syarat sah nya suatu perjanjian, perikatan tersebut dapat terjadi apabila syarat perjanjiannya terpenuhi. Menurut pasal

${ }^{9}$ R. Subekti dan R. Tjitrosudibio, 2001, Kitab Undang-Undang Hukum Perdata, (Jakarta: PT.Pradnya Paramita) hlm. 475 .
1320 KUHPerdata mengatur mengenai syarat sahnya suatu perjanjian, LPD dalam hal ini tidak bisa menjadi pihak debitur atau yang meminjam uang karena yang sebenarnya terjadi bukan LPD yang meminjam uang kepada pihak bank tetapi pribadi atau orang yaitu ketua LPD atau pengelola dari LPD tersebut dengan menggunakan objek tanah milik pribadi ketua/pengelola LPD sehingga resiko yang terjadi apabila tidak bisa memenuhi tanggung jawab membayar hutang, yang terkena dampak adalah harta kekayaan dari milik pribadi ketua/pengelola LPD tersebut bukan LPD nya. Sehingga ketika melakukan perikatan hak tanggungan, syarat-syarat perjanjianya terpenuhi karena yang bertindak adalah pribadi dari ketua atau pengelola LPD tersebut bukan LPD nya.

Akibat hukum dari perjanjian yang dibuat oleh LPD sebagai debitur dalam suatu perjanjian hak tanggungan adalah tidak sah, karena menurut pasal 1320 pada ayat (4) KUHPerdata mengenai syarat sah nya perjanjian adalah ada suatu sebab yang halal atau legal cause yang artinya sebab dari perjanjian itu sendiri yang menggambarkan keinginan atau tujuan dari kedua pihak yang berjanji. Pasal 1335 menentukan bahwa suatu perjanjian tanpa sebab atau karena sebab palsu adalah termasuk ke dalam sebab yang tidak halal. Pada pasal 1337 KUHPerdata, dengan jelas menyebutkan bahwa para pihak tidak bebas untuk mengadakan perjanjian yang menyangkut kausa yang dilarang oleh undang-undang atau yang bertentangan dengan kesusilaan dan ketertiban umum. Akibat hukum dari perjanjian yang 
dibuat bertetangan dengan kausa tersebut adalah menyebabkan perjanjian itu menjadi tidak sah atau maka perjanjian batal demi hukum.

\section{B AB III \\ PENUTUP}

\subsection{Kesimpulan}

1. LPD adalah salah satu duwe desa pakraman, merupakan wadah khusus yang mengelola duwe desa pakraman sehingga LPD tidak berwenang sebagai subjek hukum dalam perjanjian hak tanggungan. Sampai saat ini belum ada aturan yang tegas mengatur mengenai LPD sebagai subyek hukum yang dapat menjadi debitur dalam perjanjian hak tanggungan.

2. Akibat hukum dari perjanjian yang dibuat oleh LPD sebagai debitur dalam suatu perjanjian hak tanggungan adalah tidak sah, karena menurut pasal 1320 pada ayat (4) KUHPerdata mengenai syarat sah nya perjanjian adalah ada suatu sebab yang halal atau legal cause yang artinya sebab dari perjanjian itu sendiri yang menggambarkan keinginan atau tujuan dari kedua pihak yang berjanji.

\subsection{Saran}

1. 'Disarankan kepada Pemerintah Propinsi Bali dan Majelis Utama Desa Pakraman untuk bersama-sama memperjuangkan status subyek hukum LPD, sehingga status LPD dapat diakui sebagai subyek hukum oleh undangundang sehingga perjanjian yang dibuat menjadi sah secara hukum.

\section{DAFTAR PUSTAKA}

\section{Literature :}

Adul Rachmad Budiono, 2005, Pengantar Ilmu Hukum, Bayumeda, Malang.

Abdulkadir Muhammad, 2000, Hukum Perdata Indonesia, Citra Aditya Bandung

Henry Campbell Black, 1977, Black’s Law Dictionary, Fifth Edition, St. Paul Minn.West Publishing Co., USA.

M. Yahya Harahap, 2009, Hukum Perseroan Terbatas, Jakarta: Sinar Grafika.

Pasal 18A dan Pasal 1 8B Undang-Undang Dasar Negara Republik Indonesia Tahun 1945.

R. Subekti dan R. Tjitrosudibio, 2001, Kitab Undang-Undang Hukum Perdata, (Jakarta: PT. Pradnya Paramita).

Suparmo, Gatot, 2009, Hukum Perseroan Terbatas, Jakarta : Djambatan.

Stout, H.D., 1994, de Betekenissen van de wet, W.E.J. Tjeen Willink, zwole. (maarseven van hench, bevoegdheid dalam PNC, akkermaans, dkk, 1985, agleme begrippen Van staats Recht, Deed I,W.E.J. Tjeen willink Zwolle). 